\title{
IMPLANTATION IN THE PLAINS VISCACHA, LAGOSTOMUS MAXIMUS
}

\author{
CHRISTINE M. ROBERTS* AND BARBARA J. WEIR \\ Wellcome Institute of Comparative Physiology, \\ Zoological Society of London, Regent's Park, London NW1 4RY
}

(Received 30th March 1972)

\begin{abstract}
Summary. Accurately dated pregnancies were obtained in order to determine the time and mode of implantation in the plains viscacha, Lagostomus maximus. Implantation was completely interstitial and occurred antimesometrially on Day 18 post coitum. From each animal, very large numbers of single-celled and fragmenting eggs and relatively few blastocysts were flushed from the uterus up to the time of implantation. They were found at the ovarian end of the uterine horns, indicating that the blastocysts do not become spaced until just before implantation. Up to five blastocysts implanted progressively in each horn from the cervical to the ovarian end.

No morphological or histological differences could be detected along the length of the uterus. The significance of these findings is discussed in relation to the fact that only those fetuses nearest the cervix in each uterine horn survive whilst the others are resorbed early in pregnancy.
\end{abstract}

\section{INTRODUCTION}

The plains viscacha is a member of the rodent sub-order, Hystricomorpha, and is a close relative of the chinchilla. Much of the embryological literature on hystricomorphs is confined to the domestic guinea-pig; details of implantation were given by Sansom \& Hill (1931) and Blandau (1949). Some information on the early embryology of the chinchilla was provided by Hillemann, Tibbitts \& Gaynor (1959) but no observations on implantation were made. The other members of the group have been neglected and the only studies on fetal membranes and placental development known to us are those of Strahl (1905) and Becher (1921a, b) on the agouti, Perotta (1956) on the North American porcupine, of Tibbitts \& Hillemann (1959) on the chinchilla and of Hillemann \& Gaynor (1961) on the coypu. Roberts (1971) has investigated implantation in the chinchilla, cuis, degu and casiragua.

The plains viscacha has only recently been studied in captivity (Weir, 1970) and it exhibits several unusual features in its reproductive physiology (Weir, $1971 \mathrm{a}, \mathrm{b}$ ). Between 200 and 800 eggs are ovulated at each oestrus and although up to five implantation sites may be found in each uterine horn, only two

* Present address: Division of Infant Development, M.R.C. Clinical Research Centre, Watford Road, Harrow, Middlesex HAl 3UJ. 
young are usually brought to term. The two embryos that survive are those implanted nearest the cervix; the others are resorbed between Day 26 and Day 70 of the 154-day pregnancy. However, the earliest postimplantation pregnancy stage observed by Weir (1971b) was at Day 26 as no blastocysts were found in the uterus of a viscacha killed 6 days post coitum.

The present study was carried out to determine the time and mode of implantation in this species.

\section{ANIMALS AND METHODS}

The viscacha were taken from the laboratory colony described by Weir (1970) and the stages studied are shown in Table 1. Oestrus was determined by daily examination of the vaginal closure membrane and the finding of a copulatory plug or spermatozoa in the vaginal smear was taken to indicate Day 1 of pregnancy.

Table 1. The numbers of eggs and blastocysts recovered from the uterus of plains viscacha

\begin{tabular}{|c|c|c|c|c|c|c|}
\hline \multirow{2}{*}{$\begin{array}{l}\text { Viscacha } \\
\text { no. }\end{array}$} & \multirow{2}{*}{$\begin{array}{c}\text { Days } \\
\text { post coitum }\end{array}$} & \multicolumn{2}{|c|}{ Eggs } & \multicolumn{2}{|c|}{ Blastocysts } & \multirow{2}{*}{ Comment } \\
\hline & & Left & Right & Left & Right & \\
\hline $\begin{array}{l}\text { V } 196 \\
\text { V } 120\end{array}$ & $\begin{array}{r}7 \\
10\end{array}$ & $\begin{array}{l}97 \mathrm{~s} \\
55 \mathrm{~s}\end{array}$ & $\begin{array}{r}>100 f \\
82 \mathrm{~s}\end{array}$ & & & $\begin{array}{l}\text { Spermatozoa in zonae } \\
\text { Three four-cell stages, one } \\
\text { eight-cell stage }\end{array}$ \\
\hline $\begin{array}{l}\text { V } 124 \\
\text { V } 186\end{array}$ & $\begin{array}{l}13 \frac{1}{2} \\
15\end{array}$ & $\begin{array}{l}89 \mathrm{~s} \\
17 \mathrm{~s}\end{array}$ & $\begin{array}{r}166 f \\
26 s\end{array}$ & & & $\begin{array}{l}\text { Two eight-cell stages } \\
\text { No morulae or blastocysts } \\
\text { found }\end{array}$ \\
\hline $\begin{array}{l}\text { V } 181 \\
\text { V } 169\end{array}$ & $\begin{array}{l}18 \frac{1}{2} \\
18 \frac{1}{2}\end{array}$ & $\begin{array}{r}430 \mathrm{f} \\
96 \mathrm{~s}\end{array}$ & $\begin{array}{r}65 \mathrm{~s} \\
>100 \mathrm{f}\end{array}$ & $2^{*} 18 \dagger$ & $\begin{array}{l}3 * 1 \dagger \\
2 *\end{array}$ & $\begin{array}{l}\text { See Text-fig. } 1 \\
\text { Seventeen free blastocysts } \\
\text { were very small, and } \\
\text { probably unhealthy }\end{array}$ \\
\hline V 200 & 22 & 0 & 0 & $3^{*}$ & $2 * 1 \dagger$ & $\begin{array}{l}\text { Implantation site at the } \\
\text { ovarian end of the left horn }\end{array}$ \\
\hline
\end{tabular}

The uteri were examined carefully for swellings indicative of implantation sites. Some uterine horns (see Table 1) were flushed with physiological saline; others, like the ovaries, were fixed in Bouin's fluid, embedded in paraffin wax and sectioned at $5 \mu \mathrm{m}$. Initially, every tenth section was mounted in order to locate the blastocysts and then a whole mount of every implantation site was made. Mayer's haemalum and eosin was the routine stain used, but some periodic acid-Schiff (PAS) staining with diastase incubations as controls was also employed.

The uterine-horn flushings were collected in a series of embryo cups and preliminary counts were made under a stereomicroscope. The dishes were then transferred to a Zeiss Ultraphot II microscope and the contents were photo- 
graphed. After printing, the photographs were matched and more detailed counts of the numbers and egg types were made. It was difficult to cover the whole field in area and depth and the figures given in Table 1 are underestimates.

\section{RESULTS}

\section{At 7 days}

Most of the 200 ova recovered from the uterus were single-celled, but about $10 \%$ were fragmenting. Spermatozoa were seen in the zona pellucida of both types.

\section{At 10 days}

The uterus was still showing postoestrous hyperaemia but there were no macroscopic indications of implantation having occurred. A total of 137

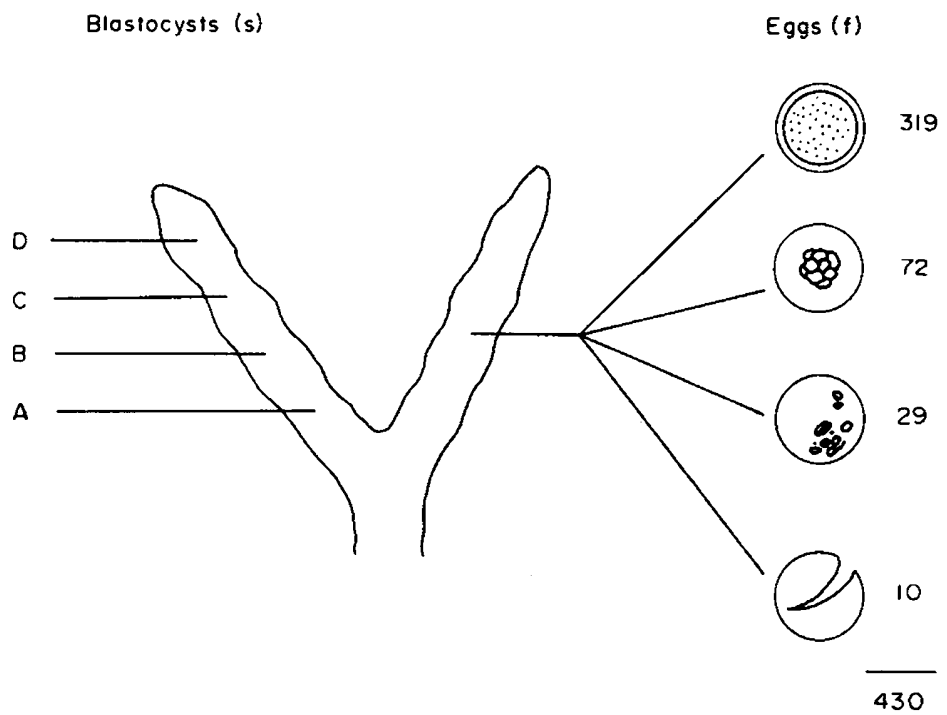

TeXT-FIG. 1. Diagrammatic representation of the condition found in Viscacha 181 on Day $18 \frac{1}{2}$ of pregnancy. Eggs flushed from the left horn were classified as follows: singlecells with unexpanded zonae (319); morulae (72); fragmenting eggs (29); and empty zonae (10). The four blastocysts (A to D) found in the right horn are described in the text.

eggs were counted in the sections of the uterine horns. Many were fragmenting but three four-cell stages and one eight-cell stage were found. Traces of the zona pellucida surrounded some of the eggs but most were denuded, presumably because of Bouin fixation. Most of the eggs were at the ovarian end of the uterine horns.

\section{At $13 \frac{1}{2}$ days}

Eighty-nine eggs were counted in the left horn of the uterus. Most of them were single-celled and appeared to be unfertilized, but two eight-cell stages were found. A small number of apparently normal morulae was found amongst 
the 166 eggs flushed from the right horn. The other eggs were single-celled or fragmenting.

\section{At 15 days}

Although both horns of the uterus were sectioned, only a few eggs were found and no morulae or blastocysts were recognized.

\section{At $18 \frac{1}{2}$ days}

Viscacha 181 . The condition found in this animal is expressed diagrammatically in Text-fig. 1, and although large numbers of assorted egg types were flushed from the left uterine horn, implantation had started $(A, B, C)$ in the right. The blastocyst (A) nearest the cervix (Pl. 1, Fig. 1) was lying immediately beneath the uterine epithelium on the antimesometrial side of the lumen. In some sections, the epithelium had a rather flattened appearance at the point of entry of the blastocyst, but no gap could be seen. The amnioembryonal ectoderm was represented by a central mass of deeply staining cells. The endoderm was below this and contained large, actively dividing cells. A thickened covering trophoblast lay above the amnioembryonal ectoderm and was closely adherent to the uterine epithelium. The parietal trophoblast was continuous with the covering trophoblast and extended around the blastocyst cavity, enclosing it completely. The nuclei of the parietal trophoblast appeared clumped in places and extensive areas of vacuolated cytoplasm were seen. Within these vacuoles, and within the blastocyst cavity, numerous tiny eosinophilic globules were visible; these may be associated with the degeneration of the parietal trophoblast. As in the guinea-pig, this layer is transient and disappears shortly after implantation, thus exposing the endoderm to the maternal tissues very early in development. The blastocyst measured $0.086 \mathrm{~mm}$ (vertical height) $\times 0.128 \mathrm{~mm}$ (maximum internal diameter) $\times 0.085 \mathrm{~mm}$ (sectional diameter); the blastocyst usually remains small until after implantation in species with complete interstitial implantation. The decidual-cell reaction radiated for about $0.5 \mathrm{~mm}$ from this implantation site. Many lymphocytes were seen infiltrating the capillaries of the stroma around the implanting blastocyst.

A second, almost identical blastocyst (B, Text-fig. 1) was found nearer the ovary. The parietal trophoblast was more compact and continuous around the blastocyst cavity. Mitoses were seen in some cells of the thickened covering trophoblast. Although similar in its state of development, this blastocyst was slightly smaller than Blastocyst A; it was $0.072 \times 0.085 \times 0.075 \mathrm{~mm}$.

Blastocyst C (Text-fig. 1) was found about half way along the uterine horn

\section{EXPLANATION OF PLATE 1}

Fig. 1. Section of Blastocyst A (see Text-fig. 1) of Viscacha 181 at $18 \frac{1}{2}$ days of pregnancy lying immediately beneath the uterine epithelium on the antimesometrial side of the lumen. The central deep-staining cells represent the amnioembryonal mass, beneath which is a layer of endodermal cells. Above, is the thickened covering trophoblast from which extends the parietal trophoblast, enclosing the blastocyst cavity. $\times 300$.

FIG. 2. Section of Blastocyst C (see Text-fig. 1) of Viscacha $18 \mathrm{I}$ at $18 \frac{1}{2}$ days of pregnancy penetrating the uterine epithelium. Note the considerable quantity of globular material within the blastocyst cavity, and also the reaction in the subepithelial tissue, on the opposite side of the lumen. $\times 300$. 
PLA'IE 1

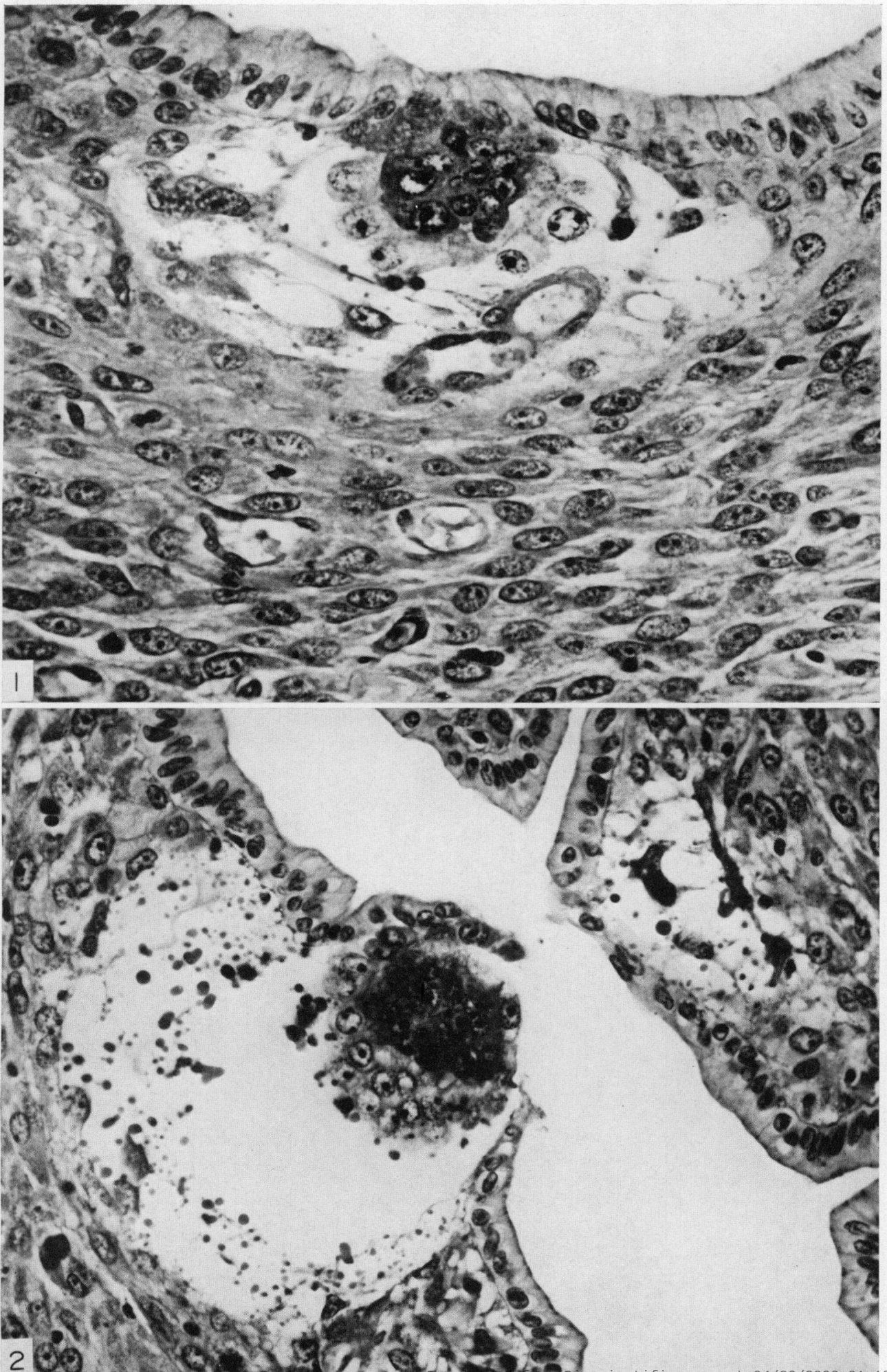

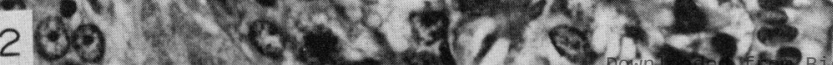



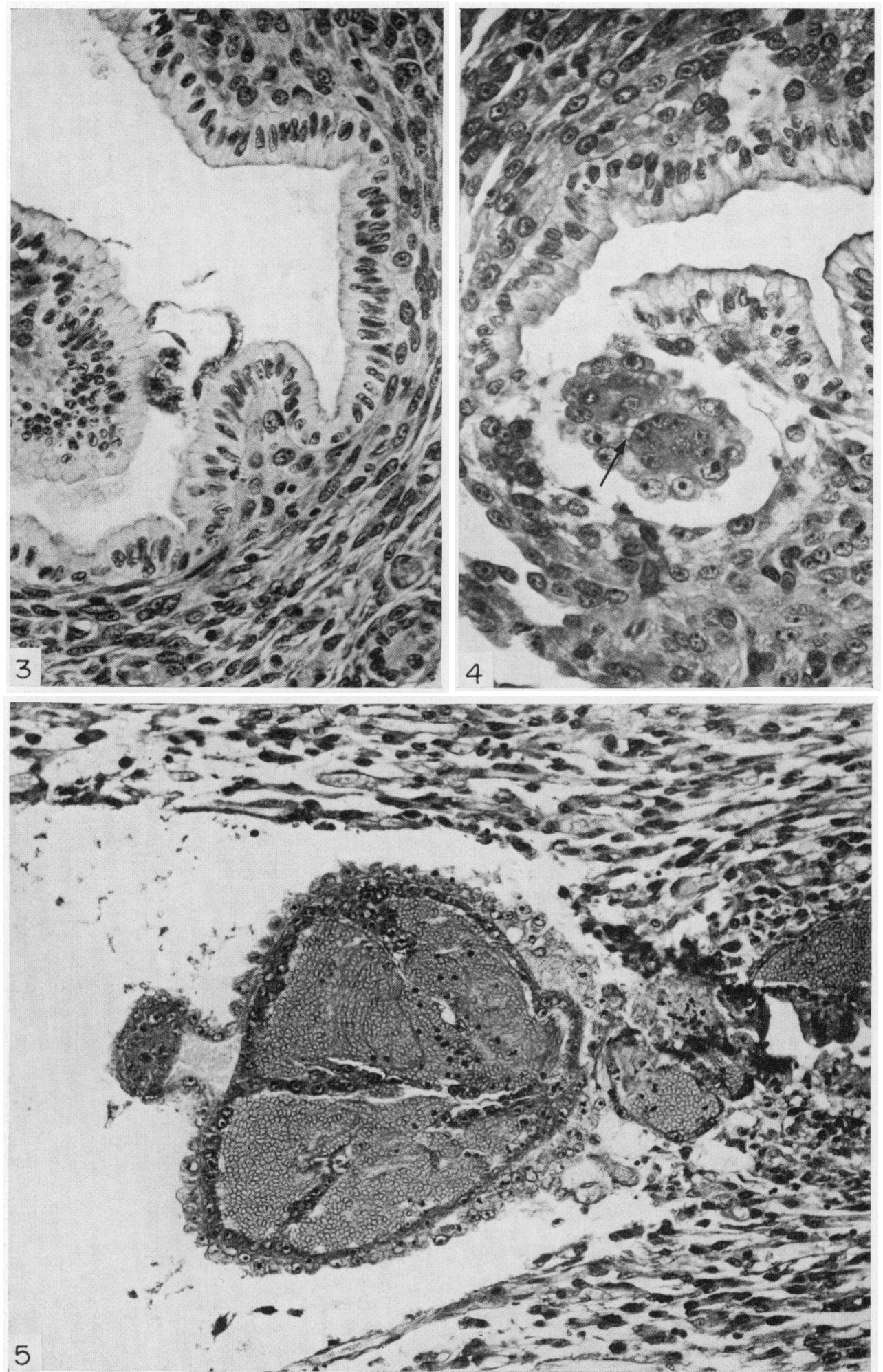
and was penetrating the uterine epithelium (Pl. 1, Fig. 2). Most of the blastocyst was under the epithelium which seemed to be growing up and around it. This may be the process of 'circumvallation' mentioned by Sansom \& Hill (1931) and by Deanesly (1971), or may simply be due to displacement. The most interesting feature of this implantation site was the large number of PAS-positive globules found in the blastocyst cavity. Similar globules were seen in vacuolated areas of the subepithelial tissues on the opposite side of the lumen (Pl. 1, Fig. 2). The nuclei of the parietal trophoblast cells were not easily distinguished although strands of cytoplasm extended from the covering trophoblast. The dimensions of this blastocyst were $0.085 \times 0.128 \times 0.075 \mathrm{~mm}$.

At the ovarian end of the horn, Blastocyst D was found attached to the uterine epithelium in an antimesometrial position (Pl. 2, Fig. 3). The embryonic disc was prominent but there was little thickening of the polar trophoblast. This blastocyst was smaller than A, B or C and measured $0.057 \times 0.043 \times 0.035$ mm.

Viscacha 169. In this animal, the right uterine horn was flushed and then fixed for sectioning. Over 100 eggs were recovered in the flushings; most were single-celled or fragmenting. Two blastocysts were found in the cervical half of this horn and they closely resembled Blastocysts A and B of Viscacha 181. The lowermost blastocyst was lying immediately beneath the uterine epithelium which appeared to be broken (PI. 2, Fig. 4). It was not possible to determine whether the epithelium had remained perforate after penetration of the blastocyst or whether it had closed and was damaged during the flushing of the horn. The latter seems the more probable since this blastocyst was slightly more advanced than A or B of Viscacha 181. The covering trophoblast had thickened to form the ectoplacental trophoblast and the endoderm had grown up to enclose it on both sides, giving the blastocyst a cylindrical appearance. The proexocoelomic cavity was visible as a tiny slit between the ectoplacental trophoblast and the amnioembryonal ectoderm. Clumped nuclei of the parietal trophoblast cells were visible but the connections between parietal and ectoplacental trophoblast were reduced. The second blastocyst was identical with $\mathrm{A}$ and $\mathrm{B}$ of Viscacha 181 but the rest of the uterine horn was too damaged by the flushing for further observations.

In the left horn, three blastocysts were found; two were implanted in the cervical third and the other was lying free in the lumen about half way along the horn. Seventeen very small, unhealthy looking blastocysts and ninety-six, mostly single-celled eggs were found at the ovarian extremity.

\section{EXPLANATION OF PLATE 2}

Fig. 3. Section of Blastocyst D (see Text-fig. 1) of Viscacha 181 at $18 \frac{1}{2}$ days of pregnancy attached to the uterine epithelium on the antimesometrial side of the lumen. $\times 300$. Fig. 4. Section of blastocyst of Viscacha 169 at $18 \frac{1}{2}$ days of pregnancy situated towards the cervical end of the uterus, and slightly more advanced in development than Blastocyst $A$ shown in Pl. 1, Fig. 1. Note the elongation of the endoderm which gives the blastocyst a cylindrical appearance. The proexocoelomic cavity (arrowed) is just visible as a small slit between the covering trophoblast and the amnioembryonal mass. $\times 200$. Fig. 5. Section of blastocyst of Viscacha 200 at 22 days of pregnancy, situated towards the cervical end of the uterus. Particularly noteworthy is the considerable quantity of extravasated maternal blood in the ectoplacental cavity. $\times 200$. 


\section{At 22 days}

No eggs were found in the uterine sections but, in the left horn, there were three implantations and in the right there were one free and two implanted blastocysts. The unimplanted blastocyst was smaller than the others and was lying in the lumen on the antimesometrial side at the ovarian end of the uterine horn. The five implanted blastocysts were at a very similar stage of development (Pl. 2, Fig. 5) but the one nearest the cervix in each horn appeared larger than the others. The endoderm had elongated and separated the amnioembryonal mass from the ectoplacental trophoblast, resulting in the cylindrical structure characteristic of hystricomorphs. The proexocoelomic cavity (Duval, 1892) is formed in the elongated endoderm and it becomes the extraembryonic coelom when it is lined with mesoderm. In some sections, traces of parietal trophoblast were seen bordering the enlarged and irregular blastocyst cavity, which thus became merged with a new cavity, the decidual cavity. The amnioembryonal mass was flattened and rounded but was still solid, although the ectoplacental cavity formed in the ectoplacental trophoblast had filled with extravasated maternal blood.

\section{Ovaries}

The ovaries (see Weir, 1971b) of thirty-one viscacha, killed at various times from Day 1 of pregnancy to term, were studied to determine when antral follicles were present. No antra were visible before Day 13 but at Day 15 some follicles showed antral formation and, after the 18th day, the ovaries of all pregnant females contained mature follicles. Accessory and true corpora lutea were present throughout gestation.

\section{DISGUSSION}

The findings reported above indicate that, although the mode of implantation resembles that of the domestic guinea-pig, there is a considerable difference in the timing for this event. All other hystricomorphs that have been studied (Roberts, 1971) have implanted by Day 8 and this is also true for the sciuromorph and myomorph rodents, even in cases of lactational delay of implantation (Blandau, 1961). The delay of implantation until Day 18 in viscacha cannot be considered as a prolonged lactational delay because viscacha rarely mate at the post-partum oestrus (Weir, 1971a) and the conceptions of the present series were initiated at normal or post-lactation oestrous periods. The delay is not proportional to the long gestation of 154 days since the long pregnancy is characteristic of most hystricomorphs. The chinchilla has a gestation period of 111 days and yet implants at Day 5, a day earlier than the domestic guineapig, which litters up to 70 days after conception (Roberts, 1971) depending on the litter size.

It seems possible that the unusual delay before implantation is connected in some way with the remarkable numbers of eggs that are lost at each oestrus in this species (Weir, 1971b). The present observations confirm the earlier report that 200 to 800 eggs are ovulated and support the suggestion of Weir (1971b) that only a small proportion are fertilized. This is contrary to the 
situation in the South African elephant shrew, Elephantulus myurus, where up to 120 eggs are ovulated and the majority are fertilized (Tripp, 1971). The low fertilization rate in the viscacha could be the result of failure of the spermatozoa to fertilize the eggs available or the inability of a large proportion of eggs to become fertilized because of their immaturity. The answer will be found only when in-vitro techniques are applied.

Although only a small proportion of the eggs are fertilized, it is apparent that more are fertilized than can, or do, implant. Thus, in Viscacha 169, seventeen unimplanted blastocysts were found in a horn where there were three implantations. When the $18 \frac{1}{2}$-day eggs represented in Text-fig. 1 were classified, it seemed that the ten empty zonae were those from which blastocysts had hatched. No more than five implantations have been found in one uterine horn and thus an excess of blastocysts over implantations seems probable. Weir (1971b) indicated that the eggs were in the uterus by Day 6 post coitum. The concentration of eggs and blastocysts at the ovarian end of the uterine lumen suggests that spacing of the blastocysts does not take place shortly after entry into the uterus. It probably occurs just before implantation at about Day 17. The theory suggested by Mossman (1937) to explain spacing of blastocysts was that the first to enter the uterus implanted close to the oviduct and produced a local refractory zone. This was shown to be inapplicable in mice by McLaren \& Michie (1959) who postulated muscular distribution mechanisms. Our findings also refute Mossman's (1937) theory since it is obvious that implantation in the viscacha occurs progressively from the cervical to the ovarian end of the uterine horn. Viscacha blastocysts may be spaced by muscular activity of the uterus as suggested for mice by McLaren \& Michie (1959) but the mechanism would have to be held in abeyance for the first 15 days or so of pregnancy, and a further explanation is needed for the excess blastocysts that appear to stay at the ovarian end of the uterus while implantation is occurring. The use of Pontamine blue to indicate incipient implantation sites (Psychoyos, 1961) may elucidate this question. A similar response has been found in the domestic guinea-pig (Orsini \& Donovan, 1971) and chinchilla (C. M. Roberts, unpublished observation).

Implantation may be initiated by a gradual rise in oestrogen secretion such as has been postulated for mice (Miller, Owen \& Emmens, 1968), although oestrogen-dependent implantation has not been indicated for the guinea-pig (Deanesly, 1960). The occurrence of antral follicles at about the same time as implantation suggests a connection. The follicles are certainly numerous but it must be questioned whether such small follicles $(200 \mu \mathrm{m})$ are capable of steroid secretion since theca interna cells are not apparent at this size (see Pl. 2, Fig. 4, Weir, 1971b).

So far as we are aware, the condition of the mesometrial subepithelial tissue shown in Pl. 1, Fig. 2 has not been described for any other implanting blastocyst. It is generally considered that the epithelial surfaces of the uterus are in apposition during life (Martin, Finn \& Carter, 1970) and that the uterine lumen is an artefact of fixation. Before implantation, a blastocyst must, therefore, be in contact with epithelium on both sides and this blastocyst $(\mathrm{C})$ appears to have exerted some effect on the subepithelial tissues of one side before 
implanting on the other. This suggests a lytic activity rather than a phagocytosis by the blastocyst (Amoroso, 1952). Once implanted, the early development of the viscacha is similar to that of other hystricomorphs (Weir, 1971b). The extravasation of maternal blood into the ectoplacental cavity has been described in Chinchilla (Roberts, 1971) and Erethizon (Perotta, 1956).

The most intriguing aspect of implantation in the viscacha is its connection with the subsequent fate of the embryos. The majority of viscacha litters contain only two young (Weir, 1971a) and these survivors were reported as being always those situated nearest the cervix in each uterine horn (Weir, 1971b). In Elephantulus myurus, implantation is restricted to an 'implantation chamber' and only one blastocyst in each horn can settle there (van der Horst \& Gillman, 1941). In Pteropus giganteus, only one uterine horn responds with a decidual reaction (Marshall, 1953). Macroscopic and microscopic examination of the uterus in non-pregnant and pregnant viscacha revealed no obvious morphological differences along the length of the horn which could account for the differential survival. There is no doubt that blastocysts implant normally at the ovarian end of the uterus since conceptuses have been found in this position (Weir, 1971b). After unilateral salpingectomy before copulation, a laparotomy at Day 40 of pregnancy indicated that, although five implantations

had occurred, only that nearest the cervix was surviving (B. J. Weir, unpublished observation). More experiments of this type and investigations of blood flow and hormonal environment are needed to reveal the uterine conditions needed for implantation. At present, it appears that the timing of implantation may be critical in determining the fate of the viscacha blastocyst.

\section{ACKNOWLEDGMENTS}

We are grateful to Dr I. W. Rowlands for his help and encouragement. The original viscacha were caught during an expedition financed by the Royal Society, the Medical Research Council and the Wellcome Trust. The laboratory work was supported by the Ford Foundation.

\section{REFERENCES}

Amoroso, E. C. (1952) Placentation. In: Marshall's Physiology of Reproduction, 3rd edn, Vol. 2, p. 270. Ed. A. S. Parkes. Longmans Green, London.

Becher, H. (1921a) Die Entwicklung des Mesoplacentariums und die Placenta bei Aguti (Dasyprocta azarae Schl.). Z. Anat. EntwGesch. 61, 337.

Becher, H. (192 Ib) Der feinere Bau der reifen Placenta von Aguti (Dasyprocta azarae Schl.). Z. Anat. EntwGesch. 61, 439.

Blandau, R. J. (1949) Observations on implantation of the guinea-pig ovum. Anat. Rec. 103, 19.

BLANDAu, R. J. (1961) Biology of eggs and implantation. In: Sex and Internal Secretions, 3rd edn, Vol. 2, p. 797. Ed. W. C. Young. Baillière, Tindal \& Cox, London.

DeanesLy, R. (1960) Implantation and early pregnancy in ovariectomized guinea-pigs. 7. Reprod. Fert. 1, 242.

DeanesLy, R. (1971) The differentiation of the decidua at ovo-implantation in the guinea-pig contrasted with that of the traumatic deciduoma. F. Reprod. Fert. 26, 91.

Duval, M. (1892) Le placenta des rongeurs, le placenta du cochon d'inde. J. Anat. Physiol., Paris, $28,58$.

Hillemann, H. H. \& Gaynor, A. I. (1961) The definitive architecture of the placenta of nutria, (Myocastor coypus) (Molina). Am. J. Anat. 109, 299. 
Hillemann, H. H., Tibbitts, F. D. \& Gaynor, A. I. (1959) Reproductive Biology in Chinchilla. National Chinchilla Breeders of America, Inc., New York.

Mclaren, A. \& Michie, D. (1959) The spacing of implantations in the mouse uterus. Mem. Soc. Endocr. 6, 65.

Marshall, A. J. (1953) The unilateral endometrial reaction in the giant fruit-bat (Pteropus giganteus Brünnich). F. Endocr. 9, 42.

MARtin, L., Fins, C. A. \& CARTER, J. (1970) Effects of progesterone and oestradiol-17 $\beta$ on the luminal epithelium of the mouse uterus. F. Reprod. Fert. 21, 461.

Miller, B. G., OWen, W. H. \& Emmens, C. W. (1968) The incorporation of tritiated uridine in the uterus and vagina of the mouse during early pregnancy. F. Endocr. 41, 189.

Mossman, H. W. (1937) The comparative morphogenesis of the fetal membranes and accessory uterine structures. Contr. Embryol. 26, 129.

Orsini, M. W. \& Donovan, B. T. (1971) Implantation and induced decidualization of the uterus in the guinea-pig, as indicated by Pontamine blue. Biol. Reprod. 5, 270.

Perotta, C. A. (1956) Fetal membranes of the New World porcupine Erithizon dorsatum. Anat. Rec. $124,345$.

Psychoyos, A. (1961) Perméabilité capillaire et decidualization utérine. C. r. hebd. Séanc. Acad. Sci., Paris, 252, 1515.

ROBERTs, C. M. (1971) The early development of some hystricomorph rodents with particular reference to Chinchilla laniger. F. Reprod. Fert. 27, 488.

SANSOM, G. S. \& Hill, J. P. (1931) Observations on the structure and mode of implantation of the blastocyst of Cavia. Trans. zool. Soc. Lond. 21, 295.

Strahl, H. (1905) Eine Placenta mit einem Mesoplacentarium. Anat. Anz. 26, 524.

Tibittts, F. D. \& Hilleman, H. H. (1959) The development and histology of the chinchilla placenta. 7. Morph. 105, 317.

TRIPP, H. R. H. (1971) Reproduction in elephant shrews (Macroscelididae) with special reference to ovulation. 7. Reprod. Fert. 26, 149.

VAN der Horst, C. J. \& Gillman, J. (1941) The numbers of eggs and surviving embryos in Elephantulus. Anat. Rec. 80, 443.

WEIR, B. J. (1970) The management and breeding of some more hystricomorph rodents. Lab. Anim. 4, 83.

WEIR, B. J. (1971a) The reproductive physiology of the plains viscacha, Lagostomus maximus. F. Reprod. Fert. 25, 355.

WEIR, B. J. (1971b) The reproductive organs of the female plains viscacha, Lagostomus maximus. $\mathcal{F}$. Reprod. Fert. 25, 365. 